\title{
Booster Dose Vaccine Response among Children Who were Primary Hepatitis B Vaccine Non-Responders and Sensitive Groups Concerning Vaccine Response
}

\author{
Birincil Hepatit B Aşı Yanıtsız Çocuklarda Hatırlatma Doz Aşı \\ Yanıtları ve Aşı Yanıtında Hassas Gruplar
}

\author{
Aysun KARA UZUN ${ }^{1}$, Bahar ÇUHACI ÇAKIR ${ }^{1}$, Aslınur ÖZKAYA PARLAKAY², Zeynep PAKSOY³
}

\author{
${ }^{1}$ Department of Social Pediatrics, University of Health Sciences, Ankara Child Health and Diseases Hematology Oncology \\ Training and Research Hospital, Ankara, Turkey \\ 2Department of Pediatric Infection, University of Health Sciences, Ankara Child Health and Diseases Hematology Oncology \\ Training and Research Hospital, Ankara, Turkey \\ ${ }^{3}$ Department of Social Pediatrics, University of Health Sciences, Ankara Child Health and Diseases Hematology Oncology \\ Training and Research Hospital, Ankara, Turkey
}

\begin{abstract}
Objective: In this study, booster dose vaccine response was evaluated after performing a vaccine schedule at 0 , 1st and 6th months among 83 children aged between 2 and 16 years who were primary hepatitis B vaccine nonresponders and we tried to determine which groups were sensitive concerning vaccine response.

Material and Methods: Euvax B vaccine which included $10 \mu \mathrm{g} \mathrm{HBsAg}$ was administered in 3 doses for the second time at 0,1 and 6 months as $0.5 \mathrm{ml}$ intramuscularly in the deltoid muscle to 83 healthy children aged between 2 and 16 years who were primary hepatitis $\mathrm{B}$ vaccine non-responders and their vaccine status was determined with tests before minor surgery. Blood tests were taken three times from children at 1, 6 and 7 months after the first vaccination and antiHBs titer was evaluated by using enzyme-linked immunosorbent assay technique.

Results: The mean age of the children was $9.3 \pm 3.6$ years (2-15,9 years). The anti-HBs geometric mean concentration was found to be $537.97 \pm 377.51 \mathrm{mlU} / \mathrm{mL}(0.6-1000)$ after the first vaccination, as $309.33 \pm 337.45 \mathrm{mlU} / \mathrm{mL}(8-1000)$ after the second vaccination and as $609.78 \pm 347.43 \mathrm{mlU} / \mathrm{mL}(11.1-1000)$ following the third vaccination. Anti-HBs positive conversion rates in $\mathrm{T} 1$ were compared in 81 children who had been checked after the first vaccination and antiHBs positive conversion rates were found to be significantly lower in children whose anti-HBs titer was under $1 \mathrm{mlU} / \mathrm{ml}$ before vaccination ( $p=0,01, Z-3.29, \cup$ 469). There was no difference concerning T6 and T7 between these two groups. Anti-HBs positive conversion rates in T6 and T7 were found to be significantly higher in children with malnutrition $(p=0.008, Z-2.56, \cup 60.5, p=0.03, Z-2.11, \cup 26.5)$.

Conclusion: When observing the rapid decrease in T6 in contrast with the two dose vaccination, it is thought that antiHBs seroconversion rates and anti-HBs geometric mean concentration are related with reminding, anti-HBs titer before vaccination and checking time of anti-HBs rather than the number of reminding doses. In fact, we believe that 3 dose vaccination is better among those children whose anti-HBs titer is under $<1 \mathrm{mlU} / \mathrm{mL}$ and who have malnutrition.
\end{abstract}

Key Words: Booster vaccination, Child, Hepatitis B virus, Unresponsiveness

öz

Amaç: Çallşmada birincil hepatit B aşı yanıtsız 2-16 yaş aralığındaki 83 çocukta, 0, 1 ve 6. ay aşı şeması uygulanarak elde edilen hatıllatma doz aşı yanıtları değerlendirilmiş ve aşı yanıtında hassas gruplar belirlenmeye çalışıımıştır.

Gereç ve Yöntemler: Küçük cerrahi girişimler öncesi yapılan tetkikler sonrasında birincil hepatit B aşı yanıtsıılı̆̆ı saptanan 2-16 yaş aralığındaki sağlıklı 83 çocuğa, 2. kez 0, 1 ve 6. aylarda 3 doz 10 gg HBsAg içeren Euvax B aşısı deltoid kasa $0.5 \mathrm{ml}$ kas içine uygulanmıştır. Çocuklardan birinci aşıdan 1, 6 ve 7 . ay sonra olmak üzere, 3 kez kan alınarak antiHBs titresi enzyme-linked immunosorbent assay tekniği ile değerlendirilmiştir.

Bulgular: Çocukların yaș ortalaması 9.3 \pm 3.6 yıl (2-15.9) bulunmuştur. Birinci așı sonrası anti-HBs ortalama geometrik konsantrasyonu $537.97 \pm 377.51 \mathrm{mlU} / \mathrm{mL}$ (0.6-1000), 2. așı sonrası $309.33 \pm 337.45 \mathrm{mlU} / \mathrm{mL}$ (8-1000), 3. așı sonrası $609.78 \pm 347.43 \mathrm{mlU} / \mathrm{mL}$ (11.1-1000) bulunmuştur. Birinci așı sonrası tetkik yapılabilen 81 çocuk arasında T1'de antiHBs-positive serokonversiyon oranı, aşı öncesi anti-HBs titresi $1 \mathrm{mlU} / \mathrm{mL}$ 'nin altında olan çocuklarda diğer gruba göre 
istatistiksel anlamlı biçimde daha düşük bulunmuştur ( $p=0.01$, Z -3.29, U 469). Bu 2 grup arasında T6 ve T7'de istatistiksel fark saptanmamıştır. Malnütrisyonlu hastalarda T6 ve T7'de anti-HBs positive serokonversiyon oranı diğer gruba göre istatistiksel anlamlı olarak daha yüksek bulunmuştur ( $p=0.008, Z$-2.56, U 60.5, $p=0.03, Z$-2.11, U 26.5).

Sonuç: İki doz așıya rağmen T6'daki hızı düșüșe bakıldığında, anti-HBs serokonversiyon oranı ve anti-HBs ortalama geometrik konsantrasyon değerleri hatırlatma doz sayısından ziyade, hatırlatma yapılmasına, aşı öncesi anti-HBs titresine ve anti-HBs titresi bakma zamanılla ilgili gözükmektedir. Ancak, aşı öncesi anti-HBs titresi $<1 \mathrm{mlU} / \mathrm{mL}$ olanlar ve malnütrisyonlu çocuklarda 3 doz aşılamanın daha doğru olacağı kanaatindeyiz.

Anahtar Sözcükler: Hatırlatma aşılaması, Çocuk, Hepatit B virüs, Cevapsızlık

\section{INTRODUCTION}

Viral hepatitis $B$ is a public health problem and there are no specific drugs to treat hepatitis B virus (HBV) infection. For susceptible populations, the most effective preventive measure is to improve immune competence by immunizing with a hepatitis B vaccine (1). Several studies have found that unresponsiveness to the primary hepatitis $B$ vaccination is seen in $1-15 \%$ of the cases $(2,3)$.

In this study, booster dose vaccine response was evaluated after performing a vaccine schedule at 0, 1 and 6 months 83 children aged between 2 and 16 years who were non-responders to the primary hepatitis $\mathrm{B}$ vaccine. Moreover we tried to determine which groups were sensitive to vaccine response.

\section{METHODS}

The study was conducted between 1 August 2015 and 1 May 2016 at the University of Health Sciences, Ankara Child Health and Diseases Hematology Oncology Training and Research Hospital. 83 children were included in the study. All of the children were informed of the completion of the first vaccine series of hepatitis B 3 doses. Hepatitis B surface (HBsAg) antigen, antibody to hepatitis B surface (anti-HBs) antigen, and antibody against hepatitis B core (anti-HBc) antigen titers were examined by enzyme-linked immunosorbent assay (ELISA) technique before any minor surgery. In children, HBsAg and anti-HBc were found (-), anti-HBs titer was found to be $<10 \mathrm{mlU} /$ $\mathrm{mL}$ and they were directed to the Well Child Unit for hepatitis B vaccination. Children with immune deficiency, chronic diseases or a history of hepatitis were excluded from the study.

Euvax B (Sanofi Pasteur Ltd., Thailand/LG Life Sciences Ltd., Korea [batch no. UVA14046]) vaccine which included $10 \mu \mathrm{g}$ HBsAg was performed by the same nurse in 3 doses for the second time at 0,1 and 6 months as $0.5 \mathrm{ml}$ intramuscularly in the deltoid muscle to the children. The vaccines were used within the dates of validity. Blood tests were taken three times from the children at 1 (T1), 6 (T6) and 7 (T7) months after the first vaccination, and anti-HBs titer was checked by ELISA method. Anti-HBs titers of $<10 \mathrm{mlU} / \mathrm{mL}$ were considered as negative; anti-HBs titers of $\geq 10 \mathrm{mlU} / \mathrm{mL}$ were considered as positive (4). 25.3\% (21/83) of the children had been vaccinated with 2 doses and 62 (74.7\%) children had been vaccinated with 3 doses. Anti-HBs titer was checked in $97.6 \%$ (81/83) of the children before the second vaccination (T1), in $74.7 \%(62 / 83)$ of the children before the third vaccination (T6) and 49.4\% (41/83) of the children one month after the third vaccination (T7).

Ethical approval was obtained for this study from University of Health Sciences, Ankara Child Health and Diseases Hematology Oncology Training and Research Hospital Ethical Committee.

\section{Statistical analysis}

The statistical software SPSS 17.0 was used for statistical analysis. Descriptive statistics were employed. Wilcoxon Signed Rank test was used for dependent groups and MannWhitney $U$ test was used for independent groups. Differences were considered statistically significant with $P$ values of $<0.05$.

\section{RESULTS}

There were 36 (43.3\%) girls and 47 (56.7\%) boys. Their mean age was 9.3 3.6 (2-15.9) years. According to body mass index percentile rates, 9 (10.8\%) of the children had malnutrition, 14 (16.8\%) of the children were obese and 60 (72.4\%) showed normal weight. Forty seven (56.6\%) of the children had been exposed to tobacco smoke. Family members or first degree relatives of twenty nine (34.9\%) children were HBV carriers.

The mean duration after the primer vaccination schedule

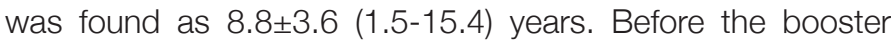
vaccination, the anti-HBs geometric mean concentrations (GMCs) of the children were found to be $2.37 \pm 2.53 \mathrm{mlU} / \mathrm{mL}$ (0.0-9.45), and the anti-HBs titer was under $<1 \mathrm{mlU} / \mathrm{mL}$ in $44.6 \%(37 / 83)$ of the children. A protective antibody titer was found in all 83 children whose anti-HBs titer was checked. AntiHBs titer was found a as $<10 \mathrm{mlU} / \mathrm{mL}$ among four children (4.9\%) whose anti-HBs titer was checked before the second vaccination, three of these children had efficient anti-HBs titer after the second vaccination and one of these children had efficient titer after the third vaccination.

Anti-HBs GMCs was found as 537.97 $\pm 377.51 \mathrm{mlU} / \mathrm{mL}$ (0.61000) in $\mathrm{T} 1,309.33 \pm 337.45 \mathrm{mlU} / \mathrm{mL}$ (8-1000) in T6 and $609.78 \pm 347.43 \mathrm{mlU} / \mathrm{mL}$ (11.1-1000) in T7. A 227 fold increase was ensured in anti-HBs GMCs after the first booster dose vaccine when compared with the levels before the vaccination. A significant decreased correlation concerning anti-HBs GMCs was found in 60 children in T1-T6 ( $p=0.000, r-0.69)$ and a 
significant increased correlation was found in 41 children in T6-T7 ( $p=0.000, r$ 0.73) and in T1-T7 ( $p=0.000, z$ 0.70). A significant relationship was observed concerning anti-HBs positive conversion rates in 60 children in T1-T6 $(\mathrm{p}=0.000, \mathrm{z}$ -4.0 , negative ranks $=39$, positive ranks $=15$, ties $=6$ ) and in 41 children in T6-T7 ( $\mathrm{p}=0.000, \mathrm{z}-4.8$, negative ranks=3, positive ranks $=32$, ties $=6)$ and in $\mathrm{T} 1-\mathrm{T} 7(\mathrm{p}=0.001, \mathrm{z}-3.2$, negative ranks=6, positive ranks=29, ties $=6$ ).

Anti-HBs positive conversion rates after the 1st, 2nd and 3rd vaccination were lower in children who had been exposed to tobacco smoke and children with obesity that will not be fully significant ( $p>0.05)$. Anti-HBs positive conversion rates in T6 and T7 were revealed significantly higher in children with malnutrition than among the others $(p=0.008, Z-2.56, \cup 60.5$, $p=0.03, Z-2.11, \cup 26.5)$.

When we compared the 81 children who had been tested after the first vaccination, anti-HBs positive conversion rates in $\mathrm{T} 1$ were found to be significantly lower in children whose anti-HBs titer was under $1 \mathrm{mlU} / \mathrm{mL}$ before the first vaccination than in the other group ( $p=0.01, Z-3.29, \cup 469)$. There was no difference for T6 and T7 between these groups ( $p>0.05$ ).

\section{DISCUSSION}

To prevent HBV infection, the World Health Organization advocated HBV vaccination of all infants in 1992, first and universal vaccination by the end of 2013 (1). Turkey is a country which has an intermediate endemicity concerning HBV infection (5). Effective control of HBV transmission in regions with high and intermediate endemicity would not be possible without the vaccination of the most vulnerable groups of the population (6). The vaccine was included in the vaccination schedule in Turkey in 1998 (7).

Although there is no hesitation about hepatitis $B$ vaccine being the most efficient way to prevent HBV infection, there are a few questions as to the duration of protection, the necessity of a booster dose and timing, and whether protection will continue if the anti-HBs titer fall below $<10 \mathrm{mlU} / \mathrm{mL}$ (8-15).

Risk factors and efficient vaccination strategies have been developing concerning hepatitis $B$ vaccine unresponsiveness which is seen in $1-15 \%$ of cases according to several studies $(2,3,8,16)$. Several factors have been associated with nonresponse to hepatitis $B$ vaccine. These factors include vaccine factors (e.g., dose, schedule, injection site) and host factors. Male gender, obesity, smoking, and chronic illness have been independently associated with unresponsiveness to hepatitis B vaccine (4). The Centers for Disease Control and Prevention have advised that individuals who do not respond to the first series of hepatitis B vaccine should complete a second three dose vaccine series. The second vaccine series should be given over the usual 0, 1, 6 month schedule (4). In this study, we have aimed to evaluate booster dose vaccine responses after using a 0,1 and 6 month vaccine schedule among the children who were unresponsive to the primary hepatitis $B$ vaccine and determine sensitive groups concerning vaccine response.

High rates of hepatitis B carriers (35\%) were found among the children's families or first degree relatives. This situation may be seen as coincidental as indeed the prevalence of this disease in our country may well be related with genetic or ethnic factors (5,17-20).

In our study, none of the children were positive for HBsAg or anti-HBc antibodies or were reported to have clinical symptoms of HBV infection during the 8.8 years after primary HBV vaccination. It has been shown that vaccine induces active production of anti-HBs antibody accompanied by HBsAg specific immunological memory that provide continuous protection in the absence of antibody. These findings also confirm what has been demonstrated in other studies $(11,12)$. Individuals whose anti-HBs levels decline to $<10 \mathrm{mlU} / \mathrm{mL}$ may not be at risk of hepatic disease since they have HBsAg specific immunological memory. Following exposure to HBV, the presence of the immunological memory rapidly leads to a robust anamnestic response, which prevents acute disease and chronic infection (12).

Protective anti-HBs titers were supplied after the three dose vaccination for all of the children in our study and results were found to be high after the first booster dose (95.1\%) and were consistent with other studies (Malaysia 94.0\% and Germany 97.2\%-99.6\%) (9.22).

In our study, anti-HBs positive conversion rates in $\mathrm{T} 1$ were determined to be significantly lower in children whose anti-HBs titer was under $1 \mathrm{mlU} / \mathrm{mL}$ before the vaccination than the other groups. In fact, there was no difference in T6 and T7 between the groups. This situation has recently been studied in order to identify genetic reasons (17-19,23,24). We therefore believe that three dose booster vaccination is suitable for these children.

Studies have shown that the hepatitis $B$ vaccination response is lower in obese children $(25,26)$. Although statistical significance was not detected in our study, anti-HBs positive conversion rates after the 1st, 2nd and 3rd vaccinations were lower in obese children. It has been shown in other studies that hepatitis $B$ vaccine response is influenced negatively in patients with malnutrition. In our study, anti-HBs positive conversion rates in $\mathrm{T} 6$ and $\mathrm{T} 7$ were seen to be significantly higher in children with malnutrition than the other group. We think that this result is associated with the immunity problems children with malnutrition often confront as well as technical problems during their vaccination (27). In our opinion, three dose booster vaccination is suitable for children with malnutrition.

Our study has limitations such as the small case group and the fact that the anti-HBs titer after the last vaccination could not be checked in the long term. 
For children with low or undetectable anti-HBs titers after hepatitis B vaccination, several methods have been developed to overcome this unresponsiveness. The current chief counter measures include using more immunogenic epitopes or replacement vaccines, increasing the number of vaccinations and doses, changing the method of vaccination, and combining the vaccine with an adjuvant or immunoregulant $(8,16,28-31)$. In our study, anti-HBs seroconversion rates and anti-HBs GMCs in T1 decreased rapidly in T6 after 5 months. Additionally, both anti-HBs seroconversion rates and anti-HBs GMCs in T6 after the third booster dose increased rapidly in $\mathrm{T7}$. So, the significant difference about the increased aspect of seroconversion rate and GMCs between $\mathrm{T} 1$ and $\mathrm{T} 7$ and the rapid decrease in $\mathrm{T} 6$ despite two dose vaccination are related with reminding, antiHBs titer before vaccination and the checking time of anti-HBs rather than the number of reminding doses $(17,32,33)$.

In conclusion, high-rated protection (95.1\%) is obtained after the first dose booster vaccination. When we examine the rapid decrease in T6 in contrast with two doses vaccination, it is thought that anti-HBs seroconversion rates and anti-HBs GMCs are related with reminding, anti-HBs titer before vaccination and the checking time of anti-HBs rather than the number of reminding doses. In our opinion, providing those children whose anti-HBs titer is under $<1 \mathrm{mlU} / \mathrm{mL}$ and who have malnutrition with three dose vaccination is more suitable. Further studies are need to concerning this subject which include larger sample groups and long-term testing of antibody titers.

\section{REFERENCES}

1. Immunization Coverage. Availablefrom:http://www.who.int/mediacentre/factsheets/fs378/en/. Accessed date: 1 Haziran, 2016

2. Zhuang $\mathrm{GH}$, Yan $\mathrm{H}$, Wang $\mathrm{XL}$. Risk factors of and mechanism for non-responsiveness to hepatitis B vaccination. Zhonghua Gan Zang Bing Za Zhi 2006;14:157-60.

3. Averhoff F, Mahoney F, Coleman P, Schatz G, Hurwitz E, Margolis $\mathrm{H}$. Immunogenicity of hepatitis B Vaccines. Implications for persons at occupational risk of hepatitis B virus infection. Am J Prev Med 1998;15:1-8.

4. http://www.cdc.gov/vaccines/pubs/pinkbook/hepb.html (8.5.2017)

5. Toy M, Önder FO, Wörmann T, Bozdayi AM, Schalm SW, Borsboom GJ, et al. Age- and region-specific hepatitis B prevalence in Turkey estimated using generalized linear mixed models: A systematic review. BMC Infectious Diseases 2011;11:337.

6. Bonanni P, Pesavento G, Boccalini S, Bechini A. Perspectives of public health: Present and foreseen impact of vaccination on the epidemiology of hepatitis B. J Hepatol 2003;39:224-9.

7. Ozmert EN. Dünya'da ve Türkiye'de aşılama takvimindeki gelişmeler. Çocuk Sağlığı ve Hastalıkları Dergisi 2008;51:168-75.

8. Jafarzadeh A, Zarei S, Shokri F. Low dose revaccination induces robust protective anti-HBs antibody response in the majority of healthy non-responder neonates. Vaccine 2008;26:269-76.

9. Behre U, Bleckmann G, Crasta PD, Leyssen M, Messier M,
Jacquet JM. Long-term anti-HBs antibody persistence and immune memory in children and adolescents who received routine childhood hepatitis B vaccination. Hum Vaccin Immunother 2012;8:813-8.

10. Gilca V, De Serres G, Boulianne N, Murphy D, De Wals P, Ouakki M. Antibody persistence and the effect of a booster dose given 5, 10 or $15 y e a r s$ after vaccinating preadolescents with a recombinant hepatitis B vaccine. Vaccine 2013;31:448-51.

11. Fitz Simons D, François G, Hall A, McMahon B, Meheus A, Zanetti A. Long-term efficacy of hepatitis B vaccine, booster policy, and impact of hepatitis B virus mutants. Vaccine 2005;23:4158-66.

12. West DJ, Calandra GB. Vaccine induced immunologic memory for hepatitis B surface antigen: Implications for policy on booster vaccination. Vaccine 1996;14:1019-27.

13. Lu CY, Chiang BL, Chi WK, Chang MH, Ni YH, Hsu HM, et al. Waning immunity to plasma-derived hepatitis $B$ vaccine and the need for boosters 15 years after neonatal vaccination. Hepatology 2004;40:1415-20.

14. McMahon BJ, Bruden DL, Petersen KM, Bulkow LR, Parkinson AJ, Nainan O, et al. Antibody levels and protection after hepatitis $B$ vaccination: results of a 15-year follow-up. Ann Intern Med 2005;142:333-41.

15. Hadler SC, Francis DP, Maynard JE, Thompson SE, Judson FN, Echenberg DF, et al. Long-term immunogenicity and efficacy of hepatitis B vaccine in homosexual men. N Engl J Med 1986; 315:209-14.

16. Pan HX, Zeng Y, Song XF, Zhang YJ, Xu K, Liang ZL, et al. Immune response to hepatitis $B$ vaccine with high antigen content in nonresponders after standard primary vaccination in Chinese adults. Vaccine 2014;17:3706-12.

17. Schonberger K, Riedel C, Ruckinger S, Mansmann U, Jilg W, Kries RV. Determinants of Long-term protection after hepatitis $B$ vaccination in infancy: A meta-analysis. Pediatr Infect Dis $J$ 2013;32:307-13.

18. Goncalves L, Albarran B, Salmen S, Borges L, Fields H, Montes H, et al. The nonresponse to hepatitis $B$ vaccination is associated with impaired lymphocyte activation. Virology 2004;326:20-8.

19. Tajiri K, Shimizu Y. Problems and future perspectives of hepatitis B virus vaccination. World J Gastroenterol 2015;21:7074-83.

20. Asturias EJ, Mayorga C, Caffaro C, Ramirez P, Ram M, Verstraeten $T$, et al. Differences in the immune response to hepatitis $B$ and Haemophilus influenzae type b vaccines in Guatemalan infants by ethnic group and nutritional status. Vaccine 2009;2:3650-4.

21. Poorolajal J, Mahmoodi M, Majdzadeh R, Nasseri-Moghaddam S, Haghdoost A, Fotouhi A. Long-term protection provided by hepatitis $B$ vaccine and need for booster dose: A meta-analysis. Vaccine 2010;28:623-31.

22. Hudu SA, Malik YA, Niazlin MT, Harmal NS, Adnan A, Alshrari AS. Antibody and immune memory persistence post infant hepatitis $B$ vaccination. Patient Prefer Adherence 2013;7:981-6.

23. Chen YS, Chu CH, Wang JH, Lin JS, Chang YC. Predictors of booster response to Hepatitis $B$ vaccine at 15 years of age: A crosssectional school-based study. Pediatr Neonatol 2015;15:174-6.

24. Salama II, Sami SM, Salama SI, Foud WA, Abdel Hamid AT, Said ZN. Persistence of protection to hepatitis $B$ vaccine and response to booster dose among children and adolescents in DakahleyaEgypt. Egypt J Immunol 2014;21:13-26.

25. Çekmez F, Canpolat FE, Erdinç K, Çetinkaya M, Akın O, Pamuk U, et al. Response to hepatitis $B$ vaccine differs by birthweight among neonates. Vaccine 2011;29:3096-7. 
26. Fan W, Chen XF, Shen C, Guo ZR, Dong C. Hepatitis B vaccine response in obesity: A meta-analysis. Vaccine 2016;34:4835-41.

27. Cuille MAR, Seck A, Njouom R, Chartier L, Sow HD, Mamadou $K A S$, et al. Low immune response to hepatitis $B$ vaccine among children in Dakar, Senegal. PLoS One 2012;7:1-4.

28. Lin CS, Xie SB, Liu J, Zhao ZX, Chong YT, Gao ZL. Effect of revaccination using different schemes among adults with low or undetectable anti-HBs titers afterhepatitis B virus vaccination. Clin Vaccine Immunol 2010;17:1548-51.

29. Velu V, Nandakumar S, Shanmugam S, Jadhav SS, Kulkarni PS, Thyagarajan SP. Comparison of three different recombinant hepatitis B vaccines: GeneVac-B, Engerix B and Shanvac B in high risk infants born to HBsAg positive mothers in India. World $J$ Gastroenterol 2007;13:3084-9.

30. Zhang Y, Jiang W, Fan Y, Wen J, Hao W, Qian M. Engineering enhancement of the immune response to HBV DNA vaccine in mice by the use of LIGHT gene adjuvant. J Virol Methods 2008;153:142-8.

31. Rapicetta M, D'Ugo E, Argentini C, Catone S, Canitano A, Giuseppetti R, et al. New perspectives for hepatitis B vaccines and immunization. Vaccine 2009;27:3271-5.
32. Chen Y, Lv H, Gu H, Cui F, Wang F, Yao J, et al. The effects of different dosage levels of hepatitis $B$ vaccine as booster on antiHBs-negative children 5-15 y after primary immunization; China, 2009-2010. Hum Vaccin Immunother 2014;10:498-504.

33. Qawasmi M, Samuh M, Glebe D, Gerlich WH, Azzeh M. Agedependent decrease of anti-HBs titers and effect of booster doses using 2 different vaccines in Palestinian children vaccinated in early childhood. Hum Vaccin Immunother 2015;11:1717-24. 